\title{
DESORPTION OF ARSENIC FROM SOIL, GOETHITE AND ZEROVALENT IRON USING SOME EXTRACTANTS UNDER DIFFERENT PH VALUES
}

\author{
Mostafa H. El-Sayed, Ali A. Abd El-Haleem* and Sayed H. El-Tohamy \\ Soils, Water and Environ. Res. Inst., Agric. Res. Center, Giza, Egypt. \\ * Soil Dept., Fac. of Agric., Benha University, Egypt.
}

\section{ABSTRACT:}

Arsenic is a toxic element that can occurs in the environment as a result of either natural processes or anthropogenic activities. The accumulation of arsenic in form of arsenate $\mathrm{As}(\mathrm{V})$ in soils and sediments threatens the health of plants, wildlife and human. Goethite $(\alpha-\mathrm{FeOOH})$, zerovalent iron (fine powder of iron metal) and clay minerals play an important role in controlling the concentration of soluble arsenic in pure water due to it is formed inner sphere surface complexes. Extraction of arsenic using phosphate, sulphate, molybdate and DTPA had been suggested as a procedure to assess its amounts. Arsenate was equilibrated with soils at $10-100 \mu \mathrm{g} \mathrm{As} \mathrm{ml}^{-1}$ surface coverage and extracted by $0.005 \mathrm{M}$ DTPA. On the other hand, it was equilibrated with goethite and zerovalent iron at $10 \mu \mathrm{g} \mathrm{As} \mathrm{ml} \mathrm{m}^{-1}$ and $\mathrm{pH}$ values of 5 and 9 as well as it was extracted by phosphate, sulphate and molybdate solutions at a ratio of I : $100 \approx$ As : each solution and $\mathrm{pH}$ values ranging from 3 to 12 .

Regarding soils, desorbed As $\left(\mu \mathrm{g} \mathrm{g}^{-1}\right)$ from both the studied loamy and clay loam soils by DTPA gradually increased with increasing initial As (V) concentration. A slight increase in the desorbed As from the loamy soil was observed with increasing its initial concentration from 30 to 40,50 to 60 and 60 to $100 \mu \mathrm{g} \mathrm{As} \mathrm{ml}{ }^{-1}$. Whereas, a relatively high increase in the desorbed As(V) from the clay loam soil was noticed with increasing the initial concentration of

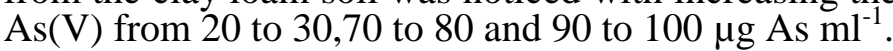

Concerning goethite, the values of $\mathrm{As}(\mathrm{V})$ desorbed by using phosphate (at $\mathrm{pH} 5$ ) depend on the $\mathrm{pH}$ values, where the relative increase percentages of As( $(\mathrm{V})$ desorbed from goethite reached 31.6, 33.0 and $70.6 \%$ at $\mathrm{pH}$ values of 3, up to 7 and 12, respectively. The corresponding relative increase percentages of As $(\mathrm{V})$ desorbed in case of phosphate (concentration of 100 times as arsenate and at $\mathrm{pH}$ 9) were greatly affected and reached 43.7, 46.0 and $75.5 \%$, respectively. In case of sulphate, the relative increase in As(V) desorbed was negligible either at $\mathrm{pH} 3$ or with increasing its value up to 7 , where the relative increase percentage was $0.34 \%$ at both $\mathrm{pH}$ values, and then greatly increased to $59.8 \%$ ) at $\mathrm{pH} 12$. As for molybdate (at initial concentration ratio of $100: 1$ of $\mathrm{MoO}_{4}$ : As), it has a greatest effect on $\mathrm{As}(\mathrm{V})$, where the relative increase percentages of $\mathrm{As}(\mathrm{V})$ desorbed reached $32.0 \%$ at $\mathrm{pH} 3$, and then sharply decreased to $0.10 \%$ with increasing $\mathrm{pH}$ up to 7 . Above $\mathrm{pH} 7$, the relative increase percentages of $\mathrm{As}(\mathrm{V})$ desorbed increased again to $58.9 \%$ at $\mathrm{pH} 12$.

With respect to zerovalent iron, phosphate (at concentration ratio of 100 solution : $1 \mathrm{As}$ and $\mathrm{pH}$ 5) had a moderate effect on $\mathrm{As}(\mathrm{V})$ desorbed at $\mathrm{pH} 3$, where the relative increase percentage was $10.1 \%$, and it tended to decrease with increasing $\mathrm{pH}$ value up to $7(7.08 \%)$. Above $\mathrm{pH} 7$, the relative increase percentage of As (V) increased again to $48.1 \%$ at $\mathrm{pH} 12$. In case of phosphate (at initial adsorption $\mathrm{pH}$ of 9), the relative increase percentages were greatly affected, i.e., 23.50, 22.09 and $55.70 \%$ at $\mathrm{pH}$ values of 3,7 and 12, respectively. Sulphate (at initial ratio of $100: 1 \mathrm{As}$ and $\mathrm{pH}$ 5) exhibited a very less quantity of $\mathrm{As}(\mathrm{V})$ desorbed at $\mathrm{pH}$ values of 3 and up to 9 as its relative increases were 0.28 and $0.08 \%$, respectively. Above $\mathrm{pH} 9.0$, the relative increase of $\mathrm{As}(\mathrm{V})$ greatly increased to $45.5 \%$ at $\mathrm{pH} 12$. While, sulphate at initial $\mathrm{pH} 9$ showed a very less relative increase percentages in $\mathrm{As}(\mathrm{V})$ desorbed at $\mathrm{pH}$ values of 3 up to 8 reached 0.93 and $1.79 \%$, respectively. Above $\mathrm{pH} 8$,

Fayoum J. Agric. Res. \& Dev., Vol.23, No.1, January, 2009 
the relative increase of $\mathrm{As}(\mathrm{V})$ greatly increased to $65.8 \%$ at $\mathrm{pH} 12$. As(V) desorbed as a result of molybdate (at initial adsorption $\mathrm{pH}$ 5) addition had no change with increasing $\mathrm{pH}$ value up to 7 (0.00), and then a pronounced increase was occurred (39.9\%) at $\mathrm{pH}$ 12. In case of molybdate (at a ratio $100 \mathrm{MoO}_{4}: 1$ As and $\mathrm{pH} 9)$, a greatest relative increase was achieved for $\mathrm{As}(\mathrm{V})$ desorbed at $\mathrm{pH} 3(51.93 \%)$, and then it sharply decreased to $1.30 \%$ with increasing $\mathrm{pH}$ up to $\mathrm{pH}$ 7. Above $\mathrm{pH} 7, \mathrm{As}(\mathrm{v})$ desorbed tended to increase again $(55.80 \%)$ at $\mathrm{pH}$ 12 .

Key words: Desorption process, arsenate, goethite, zerovelant iron, phosphate, sulphate, molybdate and variable $\mathrm{pH}$ values.

\section{INTRODUCTION}

Elevated arsenic concentrations in soil can originate from anthropogenic sources (mining, agriculture, cool combustion) and from natural occurrence of arsenic in the soil parent material. The weathering of arsenic-containing soil minerals and desorption of arsenic from soil media will increase arsenic concentration in soil solution and can contaminate drinking and irrigation water (Quaghebeur et al., 2005). High arsenic concentrations in deep well water have been verified to be associated with black foot disease, which was once common on the chianan Taiwan (Chen-Wuiing et al., 2006). Therefore, understanding arsenic desorption from soil minerals will provide important information about the fate of arsenic in the environment.

The major oxidation states of arsenic in the soil are As(V) arsenate and As(III) (arsenite), with As(V) the most dominant species in aerobic soils. Arsenate is a chemical analogue of phosphate and will therefore adsorb strongly to $\mathrm{Fe}$ and $\mathrm{Al}$ oxides and hydroxides (Hingston et al., 1971). Xu et al. (1988) observed that adsorption envelopes for $\mathrm{As}(\mathrm{V})$ on alumina $\left(\alpha-\mathrm{Al}_{2} \mathrm{O}_{3}\right)$ and kaolinite, hence $\mathrm{As}(\mathrm{V})$ anions are likely to interact mostly with the aluminol functional group in kaolinite. Recent studies have shown that arsenate predominantly forms inner-sphere complexes via ligand exchange reactions (bidentate and monodentate) with the goethite surface (Fendorf $\boldsymbol{e t} \boldsymbol{a l} ., 1997$ ) and kaolinite mineral (Arai and Sparks, 2002).

Some studies indicated that there was a significant change in rhizospher $\mathrm{pH}$ when canola (Brassica napus L.) and velvet grass (Holcus lanatus L.) took up $\mathrm{As}(\mathrm{V})$ and $\mathrm{P}$ adsorbed on kaolinite (Quaghebeur and Renglel, 2004). Therefore, it was of particular interest to study the effect of $\mathrm{pH}$ on As(V) desorption from soil matrix. Changes in $\mathrm{pH}$ greatly influence desorption of metals from soils, however, it has been suggested that $\mathrm{pH}$ effect on desorption of anionic As species are much less pronounced (Wenzel et al., 2001; Quaghebear et al., 2005).

The main objective of this study was to evaluate effect of the changes in $\mathrm{pH}$ values on $\mathrm{As}(\mathrm{V})$ desorbed from soils by using DTPA as well as from goethite and zerovalent iron by using phosphate, sulphate and molybdate.

\section{MATERIALS AND METHODS:}

To achieve the aforementioned objective, two laboratory experiments were carried out on two soil types, synthetic goethite and zerovalent iron as adsorbate complexes, the main characteristics of these materials are illustrated in the following brief notes.

a. Soil:

Two surface soil samples $(0-30 \mathrm{~cm})$ were chosen from two soil sited having different contents of calcium carbonate and clay fraction, i.e., Tamia-El Fayoum Governorate (soil I, loamy) and El Nubariya-El Behiraa Governorate (soil II, clay loam. Soil samples were air-dried, crushed, sieved through a 2-mm sieve and kept for the different lab analysis. Some physical and chemical characteristics of the studied two soils samples were determined according to Black $t$ al. (1965) and Page $\boldsymbol{e t}$ al. (1982) as well as semi-quantitative of clay minerals according to

Fayoum J. Agric. Res. \& Dev., Vol.23, No.1, January, 2009 
DESORPTION OF ARSENIC FROM SOIL, GOETHITE AND.

Brown (1961) and Venkatarathnam and Ryan (1971), the obtained results are presented in Table (1).

Table (1): Some physical, chemical and mineralogical properties of the studied two soil samples.

\begin{tabular}{|c|c|c|c|c|c|c|c|c|}
\hline Soil characteristics & $\begin{array}{c}\text { Soil } \\
\text { (I) }\end{array}$ & $\begin{array}{c}\text { Soil } \\
\text { (II) }\end{array}$ & \multicolumn{4}{|c|}{ Soil characteristics } & & $\begin{array}{c}\text { Soil } \\
\text { (II) }\end{array}$ \\
\hline $\begin{array}{l}\text { Particle size distribution \%: } \\
\text { Sand }\end{array}$ & 33.50 & 38.50 & \multicolumn{4}{|c|}{$\frac{\text { Soluble cations (soil paste, } \mathrm{mmolc} / \mathrm{L} \text { ): }}{\mathrm{Ca}^{2+}}$} & & 15.80 \\
\hline Silt & 48.00 & 27.20 & \multicolumn{4}{|l|}{$\mathrm{Mg}^{2+}$} & 32 & 4.12 \\
\hline Clay & 18.50 & 34.30 & \multicolumn{4}{|l|}{$\mathrm{Na}^{+}$} & & 22.40 \\
\hline Textural class & $\mathrm{L}$ & $\mathrm{CL}$ & \multicolumn{4}{|l|}{$\mathrm{K}^{+}$} & 2. & 0.65 \\
\hline Soil pH* & 8.10 & 8.40 & \multicolumn{4}{|c|}{ Soluble anions (soil paste, mmolc/L): } & \multirow[b]{2}{*}{0.00} & \\
\hline $\mathrm{CaCO}_{3}$ content $\%$ & 4.83 & 27.10 & \multicolumn{4}{|c|}{$\mathrm{CO}_{3}^{2-}$} & & 0.00 \\
\hline Organic matter content $\%$ & 0.28 & 0.35 & \multicolumn{4}{|l|}{$\mathrm{HCO}_{3}^{-}$} & 1.62 & 2.69 \\
\hline $\mathrm{CEC}\left(\mathrm{c} \mathrm{mol}_{\mathrm{c}} \mathrm{kg}^{-1}\right.$ soil $)$ & 14.75 & 15.60 & \multicolumn{4}{|l|}{$\mathrm{Cl}^{-}$} & 495.0 & 20.41 \\
\hline $\mathrm{ECe}(\mathrm{dS} / \mathrm{m}$, paste extract $)$ & 52.80 & 4.27 & \multicolumn{4}{|l|}{$\mathrm{SO}_{4}{ }^{2-}$} & & 19.87 \\
\hline$\frac{\text { Semi-quantitative of clay \%: }}{\text { Smectites }}$ & \multirow{4}{*}{$\begin{array}{c}50.57 \\
22.75 \\
14.22 \\
8.38\end{array}$} & \multirow{3}{*}{$\begin{array}{l}5.15 \\
62.95\end{array}$} & \multirow{3}{*}{ Metal } & availabl & ntents of & ne $\mathrm{h}$ & vy & als: \\
\hline Smectites & & & & Availab & $\mathrm{mg} / \mathrm{kg})$ & \multicolumn{3}{|c|}{ Total $(\mathrm{mg} / \mathrm{kg})$} \\
\hline \multirow{2}{*}{$\begin{array}{l}\text { Kaolinite } \\
\text { Illite } \\
\text { Vermiculite }\end{array}$} & & & & Soil (I) & Soil (II) & \multicolumn{2}{|c|}{ Soil (I) } & Soil (II) \\
\hline & & \multirow{3}{*}{$\begin{array}{c}9.72 \\
4.63 \\
15.30 \\
2.25\end{array}$} & $\mathrm{Fe}$ & 13.40 & 13.70 & \multicolumn{2}{|c|}{20700} & 19000 \\
\hline \multirow{2}{*}{$\begin{array}{l}\text { Palygorskite } \\
\text { Chlorite }\end{array}$} & \multirow{2}{*}{$\begin{array}{c}-- \\
4.08\end{array}$} & & $\mathrm{Cd}$ & 0.04 & 0.01 & \multicolumn{2}{|c|}{3.10} & 1.05 \\
\hline & & & As & $\mathrm{nd}^{* *}$ & $\mathrm{nd}^{* *}$ & \multicolumn{2}{|c|}{$\mathrm{nd}^{* *}$} & $\mathrm{nd}^{* *}$ \\
\hline
\end{tabular}

Soil $(\mathrm{I})=$ Tamia, soil $(\mathrm{II})=$ Nubariya, $\mathrm{L}=$ Loamy, $\mathrm{Cl}=$ Clay loam, $* 1: 2.5$ soil water suspension, $* *$ not detected

\section{b. Synthesis of goethite:}

Goethite was synthesized through a lab experiment according to the procedure of Schwertmann and Cornell (991) as follows; $100 \mathrm{~mL}$ of $1 \mathrm{M}$ $\mathrm{Fe}\left(\mathrm{NO}_{3}\right)_{3}$ freshly prepared, were poured into a $2 \mathrm{~L}$-polyethlene bottle, and $180 \mathrm{~mL}$ of $5 \mathrm{M} \mathrm{NaOH}$ were added rapidly with stirring to the bottle, the solution was immediately diluted to $2 \mathrm{~L}$ with deionized water and hold in a closed polyethylene bottle at $65{ }^{\circ} \mathrm{C}$ for $70 \mathrm{hrs}$. During this period, the voluminous red brown suspension of ferrihydrite is converted to a compact, yellow brown precipitate of goethite. The reaction bottle was removed from the oven and its content was washed with deionized water and the $\mathrm{pH}$ in the bottle was adjusted to 7.0 with 6 $\mathrm{M} \mathrm{HCI}$ or $2 \mathrm{M} \mathrm{NaOH}$. The suspension was dialyzed in deionized water with a continuous stirring until the electrical conductivity of dialysis water became $6 \mu \mathrm{S} / \mathrm{m}$. The dialyzed goethite suspension was kept in bottles for experimental use. Iron was determined in goethite suspension by taking one $\mathrm{mL}$ of the suspension in a $50 \mathrm{~mL}$-beaker containing $4 \mathrm{~mL}$ of $6 \mathrm{M} \mathrm{HCl}$ and heated on a hotplate till the goethite was completely dissolved. The clear suspension was transferred quantitively to a $50-\mathrm{mL}$ volumetric flask and brought to volume using deionized water. From that solution one $\mathrm{mL}$ was taken and diluted to a $100 \mathrm{~mL}$ using deionized water. Iron was measured in the last solution using Atomic Absorption Spectroscopy (Perkin Elmer 3300). The concentration of goethite in the final suspension was $32 \mathrm{gL}^{-1}$. A small portion of goethite suspension was taken, freeze-dried and the identity of goethite was confirmed by powder X-ray diffraction analysis as presented in Fig. (1).

\section{c. Zerovalent iron:}

This material represented by a fine powder of iron metal, however, either the negative or positive charges on particle charged surface sites were synthesized as a result of the changes on the $\mathrm{pH}$ values in the reaction media (Raven $\boldsymbol{e t}$ al., 1998). Desorption processes of arsenate $\mathrm{As}(\mathrm{V})$ from soil, synthetic goethite $(\alpha-$ $\mathrm{FeOOH}$ ) and zerovalent iron (fine powder of iron metal) under different $\mathrm{pH}$ values, with a back ground of $0.1 \mathrm{M} \mathrm{NaCl}$, were carried out throughout two laboratory experiments as follows:

Fayoum J. Agric. Res. \& Dev., Vol.23, No.1, January, 2009 


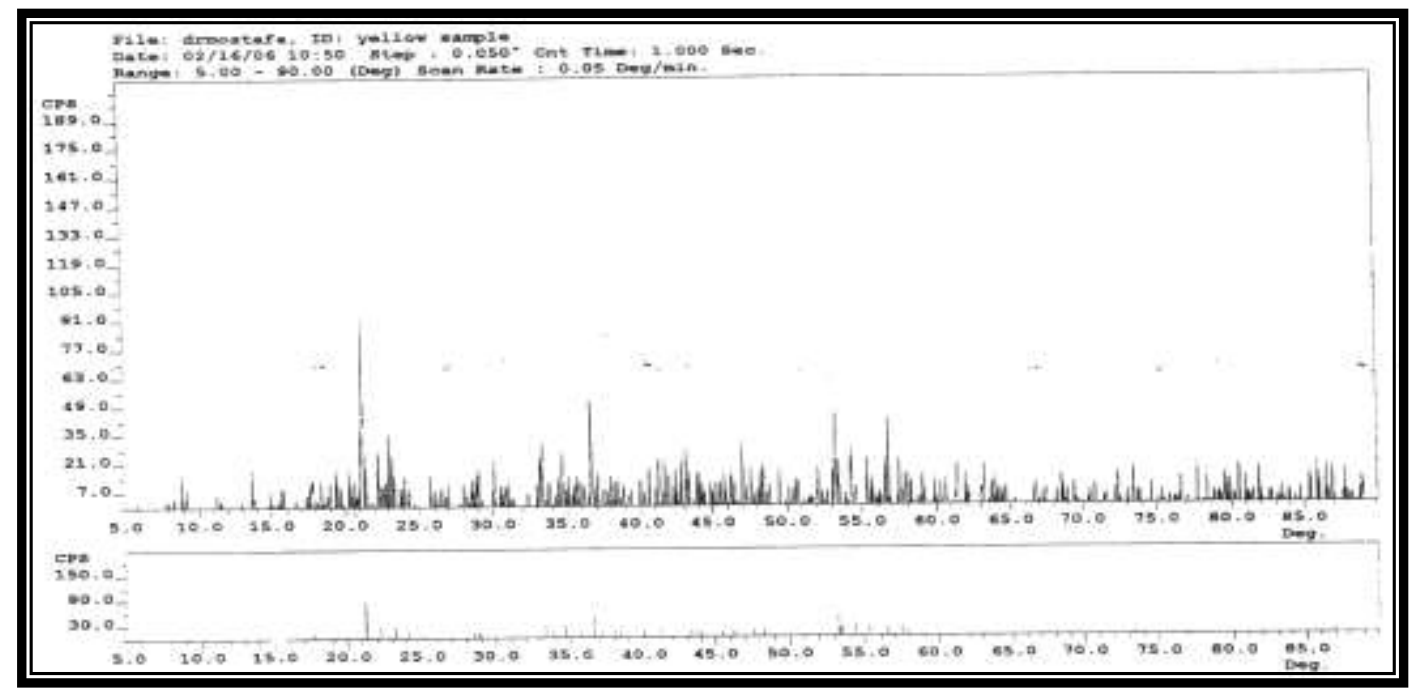

Fig. (1): X-ray diffraction analysis of synthetic goethite

\section{Experiment I:}

The first laboratory experiment was executed on the studied two soils, where a portion of one gram of each soil (loamy or clay loam) was equilibrated with $25 \mathrm{ml}$ of $\left(\mathrm{AsO}_{4}^{3-}\right)$ [As(V)] solution having 10-100 $\mu \mathrm{g} \mathrm{As} \mathrm{ml}^{-1}$ in presence of $0.1 \mathrm{M} \mathrm{NaCl}$ as ionic strength buffer for $24 \mathrm{hrs}$. Samples were shaken for $16 \mathrm{hrs}$, centrifuged, filtered and the filtrates were collected. To the settled samples, which remained in the centrifuge tubes, $20 \mathrm{ml}$ of $0.005 \mathrm{M}$ DTPA solution were added. The tubes were shaken for two hrs, centrifuged at $3000 \mathrm{rpm}$ for one min, filtered and As concentration in the filtrate was determined using Inductively Coupled Plasma Spectrometry instrument (Plasma JY Ultima).

\section{Experiment II:}

The second laboratory experiment was conduced on both goethite and zerovalent iron, where a portion of $50 \mathrm{~mL}$ goethite suspension or $1 \mathrm{~g}$ zerovalent iron, was equilibrated with $500 \mathrm{~mL}$ as a solution had $10 \mu \mathrm{g} \mathrm{As} \mathrm{mL}^{-1}$ in presence of $0.1 \mathrm{M} \mathrm{NaCl}$ as ionic strength buffer for $24 \mathrm{hrs}$. After adjusting the $\mathrm{pH}$ value to be 5 or 9 , sub-samples of $10 \mathrm{~mL}$ were taken and placed in centrifuge tubes, and then $10 \mathrm{~mL}$ of phosphate, sulphate or molybdate solutions were added to obtain a desire ratio of 1:100 for As : each one of the studied solutions. To the centrifuge tubes, which did not receive any anion of the abovementioned ones, deionized water was added instead of them. The $\mathrm{pH}$ value of these samples was adjusted to be in a range of 3-12, and such samples were shaken for $4 \mathrm{hrs}$, centrifuged for 30 min at $3000 \mathrm{rpm}$ and filtered through $0.2-\mu \mathrm{m}$ membrane filters. Arsenic concentration was measured with using the (Plasma JY Ultima).

\section{RESULTS AND DISCUSSION:}

\section{Desorption of arsenic from soils, goethite and zerovalent iron:} a. Soil:

Many of scientific studies in environmental soil chemistry have focused on the adsorption or sorption of ions and molecules on soils. Desorption process is also extremely of importance, this is particularly true for soils that are already contaminated. It is often observed that desorption is more difficult process than adsorption and that not all of the adsorbate is desorbate, i.e., the reactions appear to be irreversible. Such apparent irreversible is commonly referred to as hysteresis or non-singularity.

Fayoum J. Agric. Res. \& Dev., Vol.23, No.1, January, 2009 
Desorbed values of $\mathrm{As}(\mathrm{V}) \mathrm{AsO}_{4}{ }^{3-}$ ] from loamy soil by DTPA solution increased gradually with increasing initial $\mathrm{As}(\mathrm{V})$ concentration from 10 to 30, and from 60 to $90 \mu \mathrm{g} \mathrm{As} \mathrm{mL}^{-1}$ (Table 2). With different rates, As(V) desorption tended to increase with increasing initial $\mathrm{As}(\mathrm{V})$ concentration, i.e., a moderate increase in the $\mathrm{As}(\mathrm{V})$ desorbed was occurred when initial $\mathrm{As}(\mathrm{V})$ concentration increased from 60 to $80 \mu \mathrm{g} \mathrm{As} \mathrm{mL}^{-1}$ in the solution. However, a slight increase in the desorbed $A s(V)$ was observed with increasing its initial concentrations from 30 to 60 and from 90 to $100 \mu \mathrm{g}$ As $\mathrm{mL}^{-1}$. Desorbed As(V) \% was computed for each initial concentration, and the greatest relative increase percentages of 39.0 , 39.4 and $40.5 \%$ were accompanied with the initial concentrations of 90,30 and $80 \mu \mathrm{g} \mathrm{As} \mathrm{mL}{ }^{-1}$, respectively.

Table (2): Arsenate desorption from loamy soil by DTPA, under experimental condition of $0.1 \mathrm{M} \mathrm{NaCl}$ as ionic strength and concentrations of 10-100 $\mu \mathrm{g} \mathrm{As} \mathrm{mL}^{-1}$.

\begin{tabular}{|c|c|c|c|c|c|}
\hline \multirow{2}{*}{$\begin{array}{c}\text { Initial } \\
\begin{array}{c}\text { concentration of } \\
\text { As }\left(\mu \mathrm{g} \mathrm{mL}^{-1}\right)\end{array}\end{array}$} & $\begin{array}{c}\text { Concentration } \\
\left(\mu \mathrm{g} \mathrm{mL}^{-1}\right)\end{array}$ & $\begin{array}{c}\text { Quantity }(\mu \mathrm{g} \\
\left.\mathrm{g}^{-1}\right)\end{array}$ & $\begin{array}{c}\text { Concentration } \\
\left(\mu \mathrm{g} \mathrm{mL}^{-1}\right)\end{array}$ & $\begin{array}{c}\text { Quantity } \\
\left(\mu \mathrm{g} \mathrm{g}^{-1}\right)\end{array}$ & $\%$ \\
\hline 10.0 & 5.55 & 111 & 1.36 & 27.2 & 24.5 \\
\hline 20.0 & 13.4 & 164 & 2.52 & 50.4 & 30.7 \\
\hline 30.0 & 22.3 & 193 & 3.80 & 76.0 & 39.4 \\
\hline 40.0 & 26.6 & 335 & 4.10 & 82.0 & 24.5 \\
\hline 50.0 & 31.5 & 213 & 5.65 & 113 & 26.5 \\
\hline 60.0 & 38.7 & 284 & 6.09 & 122 & 38.4 \\
\hline 70.0 & 55.8 & 355 & 6.84 & 137 & 38.6 \\
\hline 80.0 & 65.2 & 370 & 7.48 & 150 & 40.5 \\
\hline 90.0 & 71.5 & 462 & 9.02 & 180 & 39.0 \\
\hline 100.0 & 78.6 & 535 & 9.22 & 184 & 34.4 \\
\hline
\end{tabular}

Concerning clay loam soil, data in Table (3) showed a greatest relative increase in desorbed $\mathrm{As}(\mathrm{V})$ was noticed with increasing the initial $\mathrm{As}(\mathrm{V})$ concentration from 20 to 30,70 to $80 \mu \mathrm{g} \mathrm{As} \mathrm{mL}^{-1}$.

Table (3): Arsenate desorption from clay loam soil by DTPA, under experimental condition of $0.1 \mathrm{M} \mathrm{NaCl}$ as ionic strength and concentrations of 10-100 $\mu \mathrm{g} \mathrm{As} \mathrm{mL}{ }^{-1}$.

\begin{tabular}{|c|c|c|c|c|c|}
\hline $\begin{array}{c}\text { Initial } \\
\begin{array}{c}\text { concentration of } \\
\text { As }\left(\mu \mathrm{g} \mathrm{mL}^{-1}\right)\end{array}\end{array}$ & $\begin{array}{c}\text { Concentration } \\
\left(\mu \mathrm{g} \mathrm{mL}^{-1}\right)\end{array}$ & $\begin{array}{c}\text { Quantity }(\mu \mathrm{g} \\
\left.\mathrm{g}^{-1}\right)\end{array}$ & $\begin{array}{c}\text { Concentration } \\
\left(\mu \mathrm{gL} \mathrm{m}^{-1}\right)\end{array}$ & $\begin{array}{c}\text { Quantity }(\mu \mathrm{g} \\
\left.\mathrm{g}^{-1}\right)\end{array}$ & $\%$ \\
\hline 10.0 & 6.84 & 79 & 1.08 & 21.6 & 27.3 \\
\hline 20.0 & 15.6 & 109 & 2.01 & 40.2 & 36.9 \\
\hline 30.0 & 23.1 & 173 & 3.22 & 64.4 & 37.2 \\
\hline 40.0 & 31.3 & 216 & 3.94 & 78.8 & 36.5 \\
\hline 50.0 & 40.4 & 241 & 4.59 & 91.8 & 38.1 \\
\hline 60.0 & 48.1 & 297 & 5.54 & 111 & 37.4 \\
\hline 70.0 & 57.5 & 312 & 6.12 & 122 & 39.1 \\
\hline 80.0 & 66.6 & 336 & 7.34 & 147 & 43.8 \\
\hline 90.0 & 73.6 & 411 & 8.07 & 161 & 39.2 \\
\hline 100.0 & 79.6 & 511 & 8.60 & 172 & 34.7 \\
\hline
\end{tabular}

However, a moderate increase was observed with increasing the initial As (V) concentration from 10 to $90 \mu \mathrm{g}$ As $\mathrm{mL}^{-1}$. The greatest As(V) desorbed percentages were observed with the low coverage of $\mathrm{As}(\mathrm{V})$, which were accompanied with the low initial As(V) concentration, i.e., almost 43.7 and 39.3 $\%$ of adsorbed As $(\mathrm{V})$ were desorbed using DTPA solution when the initial As(V) concentrations were 70 and $80 \mu \mathrm{g}$ As $\mathrm{mL}^{-1}$, respectively.

Fayoum J. Agric. Res. \& Dev., Vol.23, No.1, January, 2009 


\section{b. Goethite:}

Desorption of arsenic by phosphate:

Arsenic as arsenate was added to the goethite suspension at a low-coverage rate of $10 \mu \mathrm{g} \mathrm{As} \mathrm{mL}^{-1}$ to ensure a completely adsorption on goethite surfaces at $\mathrm{pH}$ values of 5 and 9 (Tables 4 and 5).

Table (4): Arsenate desorption from goethite, at the initial $\mathrm{pH} \mathrm{5}$, by $\mathrm{PO}_{4}, \mathrm{SO}_{4}$ and $\mathrm{MoO}_{4}$ under a wide range of $\mathrm{pH}$, concentration of $10 \mu \mathrm{g} \mathrm{As} \mathrm{mL}{ }^{-1}$ and $0.1 \mathrm{M}$ $\mathrm{NaCl}$ as ionic strength.

\begin{tabular}{|c|c|c|c|c|c|c|c|c|}
\hline \multirow{2}{*}{ 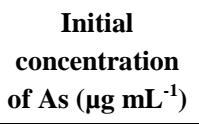 } & \multicolumn{3}{|c|}{ Adsorbed As } & \multicolumn{3}{|c|}{ Desorbed As } & \multirow[b]{2}{*}{ Final pH } & \multirow{2}{*}{$\begin{array}{c}\text { Desorbed } \\
\text { As }\end{array}$} \\
\hline & $\begin{array}{c}\text { Initial } \\
\mathbf{p H}\end{array}$ & $\begin{array}{c}\text { Concentration } \\
\left(\mu \mathrm{g} \mathrm{mL}^{-1}\right)\end{array}$ & $\begin{array}{l}\text { Quantity } \\
\left(\mu \mathrm{g} \mathrm{g}^{-1}\right)\end{array}$ & $\begin{array}{c}\text { Initial } \\
\text { pH }\end{array}$ & $\begin{array}{c}\text { Concentration } \\
\left(\mu \mathrm{g} \mathrm{mL} \mathbf{L}^{-1}\right)\end{array}$ & $\begin{array}{c}\text { Quantity } \\
\left(\mu g^{-1}\right)\end{array}$ & & \\
\hline \multicolumn{9}{|c|}{$\mathrm{PO}_{4}$} \\
\hline 10 & 5.00 & 0.026 & 3117 & 3.00 & 1.56 & 978 & 3.30 & 31.4 \\
\hline 10 & 5.00 & 0.026 & 3117 & 4.00 & 1.57 & 983 & 4.15 & 31.5 \\
\hline 10 & 5.00 & 0.026 & 3117 & 5.00 & 1.55 & 966 & 4.91 & 31.0 \\
\hline 10 & 5.00 & 0.026 & 3117 & 6.00 & 1.58 & 986 & 5.57 & 31.6 \\
\hline 10 & 5.00 & 0.026 & 3117 & 7.00 & 1.66 & 1034 & 6.46 & 33.2 \\
\hline 10 & 5.00 & 0.026 & 3117 & 8.00 & 1.84 & 1148 & 7.34 & 36.8 \\
\hline 10 & 5.00 & 0.026 & 3117 & 9.00 & 2.14 & 1335 & 7.60 & 42.8 \\
\hline 10 & 5.00 & 0.026 & 3117 & 10.00 & 2.39 & 1494 & 7.76 & 47.9 \\
\hline 10 & 5.00 & 0.026 & 3117 & 11.00 & 2.85 & 1783 & 10.15 & 57.2 \\
\hline 10 & 5.00 & 0.026 & 3117 & 12.00 & 3.52 & 2201 & 11.36 & 70.6 \\
\hline \multicolumn{9}{|c|}{$\mathrm{SO}_{4}$} \\
\hline 10 & 5.00 & 0.026 & 3117 & 3.00 & 0.017 & 10.6 & 3.28 & 0.34 \\
\hline 10 & 5.00 & 0.026 & 3117 & 4.00 & 0.020 & 12.5 & 4.09 & 0.40 \\
\hline 10 & 5.00 & 0.026 & 3117 & 5.00 & 0.022 & 13.8 & 4.44 & 0.44 \\
\hline 10 & 5.00 & 0.026 & 3117 & 6.00 & 0.020 & 12.5 & 4.74 & 0.40 \\
\hline 10 & 5.00 & 0.026 & 3117 & 7.00 & 0.017 & 10.6 & 5.55 & 0.34 \\
\hline 10 & 5.00 & 0.026 & 3117 & 8.00 & 0.201 & 126.0 & 6.26 & 4.03 \\
\hline 10 & 5.00 & 0.026 & 3117 & 9.00 & 0.540 & 338.0 & 6.52 & 10.80 \\
\hline 10 & 5.00 & 0.026 & 3117 & 10.00 & 0.778 & 486.0 & 6.81 & 15.60 \\
\hline 10 & 5.00 & 0.026 & 3117 & 11.00 & 1.330 & 833.0 & 8.43 & 26.70 \\
\hline 10 & 5.00 & 0.026 & 3117 & 12.00 & 2.990 & 1866.0 & 11.72 & 59.90 \\
\hline \multicolumn{9}{|c|}{$\mathrm{MoO}_{4}$} \\
\hline 10 & 5.00 & 0.026 & 3117 & 3.00 & 1.600 & 997.0 & 3.24 & 32.00 \\
\hline 10 & 5.00 & 0.026 & 3117 & 4.00 & 1.090 & 681.0 & 5.02 & 21.90 \\
\hline 10 & 5.00 & 0.026 & 3117 & 5.00 & 0.837 & 523.0 & 5.36 & 16.80 \\
\hline 10 & 5.00 & 0.026 & 3117 & 6.00 & 0.335 & 209.0 & 5.64 & 6.72 \\
\hline 10 & 5.00 & 0.026 & 3117 & 7.00 & 0.005 & 3.1 & 6.21 & 0.10 \\
\hline 10 & 5.00 & 0.026 & 3117 & 8.00 & 0.021 & 13.1 & 6.38 & 0.42 \\
\hline 10 & 5.00 & 0.026 & 3117 & 9.00 & 0.469 & 293.0 & 6.66 & 9.40 \\
\hline 10 & 5.00 & 0.026 & 3117 & 10.00 & 0.781 & 488.0 & 6.76 & 15.70 \\
\hline 10 & 5.00 & 0.026 & 3117 & 11.00 & 1.970 & 1233.0 & 10.30 & 39.60 \\
\hline 10 & 5.00 & 0.026 & 3117 & 12.00 & 2.940 & 1838.0 & 11.76 & 59.00 \\
\hline
\end{tabular}

Fayoum J. Agric. Res. \& Dev., Vol.23, No.1, January, 2009 
DESORPTION OF ARSENIC FROM SOIL, GOETHITE AND...........

Table (5): Arsenate desorption from goethite, at the initial $\mathrm{pH} 9$, by $\mathrm{PO}_{4}, \mathrm{SO}_{4}$ and $\mathrm{MoO}_{4}$ under a wide range of $\mathrm{pH}$, concentration of $10 \mu \mathrm{g} \mathrm{As} \mathrm{mL}$ and $0.1 \mathrm{M} \mathrm{NaCl}$ as ionic strength.

\begin{tabular}{|c|c|c|c|c|c|c|c|c|}
\hline \multirow{2}{*}{$\begin{array}{c}\text { Initial } \\
\text { concentration } \\
\text { of As }\left(\mu \mathrm{g} \mathrm{mL} L^{-1}\right)\end{array}$} & \multicolumn{3}{|c|}{ Adsorbed As } & \multicolumn{3}{|c|}{ Desorbed As } & \multirow{2}{*}{$\begin{array}{c}\text { Final } \\
\mathrm{pH}\end{array}$} & \multirow{2}{*}{$\begin{array}{c}\text { Desorbed } \\
\text { As }\end{array}$} \\
\hline & $\begin{array}{c}\text { Initial } \\
\mathrm{pH}\end{array}$ & $\begin{array}{c}\text { Concentration } \\
\left(\mu \mathrm{g} \mathrm{mL}^{-1}\right)\end{array}$ & \begin{tabular}{|c|} 
Quantity \\
$\left(\mu \mathrm{g} \mathrm{g}^{-1}\right)$
\end{tabular} & \begin{tabular}{|c|} 
Initial \\
$\mathrm{pH}$
\end{tabular} & $\begin{array}{c}\text { Concentration } \\
\left(\mu \mathrm{g} \mathrm{mL}^{-1}\right)\end{array}$ & $\begin{array}{l}\text { Quantity } \\
\left(\mu \mathrm{g} \mathrm{g}^{-1}\right)\end{array}$ & & \\
\hline \multicolumn{9}{|c|}{$\mathrm{PO}_{4}$} \\
\hline 10 & 9.00 & 0.266 & 3042 & 3.00 & 2.130 & 1329.0 & 2.92 & 43.70 \\
\hline 10 & 9.00 & 0.266 & 3042 & 4.00 & 1.960 & 1225.0 & 4.04 & 40.30 \\
\hline 10 & 9.00 & 0.266 & 3042 & 5.00 & 2.000 & 1249.0 & 4.66 & 41.10 \\
\hline 10 & 9.00 & 0.266 & 3042 & 6.00 & 2.260 & 1414.0 & 6.32 & 46.50 \\
\hline 10 & 9.00 & 0.266 & 3042 & 7.00 & 2.250 & 1406.0 & 6.60 & 46.20 \\
\hline 10 & 9.00 & 0.266 & 3042 & 8.00 & 2.330 & 1456.0 & 7.01 & 47.90 \\
\hline 10 & 9.00 & 0.266 & 3042 & 9.00 & 2.440 & 1526.0 & 7.36 & 50.20 \\
\hline 10 & 9.00 & 0.266 & 3042 & 10.00 & 2.630 & 1644.0 & 8.19 & 54.10 \\
\hline 10 & 9.00 & 0.266 & 3042 & 11.00 & 3.080 & 1923.0 & 10.60 & 63.20 \\
\hline 10 & 9.00 & 0.266 & 3042 & 12.00 & 3.680 & 2297.0 & 11.43 & 75.50 \\
\hline \multicolumn{9}{|c|}{$\mathrm{SO}_{4}$} \\
\hline 10 & 9.00 & 0.266 & 3042 & \begin{tabular}{|l|}
3.00 \\
\end{tabular} & 0.022 & 13.8 & 2.88 & 0.45 \\
\hline 10 & 9.00 & 0.266 & 3042 & 4.00 & 0.015 & 9.4 & 4.01 & 0.31 \\
\hline 10 & 9.00 & 0.266 & 3042 & 5.00 & 0.019 & 11.9 & 4.26 & 0.39 \\
\hline 10 & 9.00 & 0.266 & 3042 & 6.00 & 0.033 & 20.6 & 5.22 & 0.68 \\
\hline 10 & 9.00 & 0.266 & 3042 & 7.00 & 0.043 & 26.9 & 5.66 & 0.88 \\
\hline 10 & 9.00 & 0.266 & 3042 & 8.00 & 0.166 & 104.0 & 6.12 & 3.41 \\
\hline 10 & 9.00 & 0.266 & 3042 & 9.00 & 0.202 & 126.0 & 6.31 & 4.15 \\
\hline 10 & 9.00 & 0.266 & 3042 & 10.00 & 1.500 & 934.0 & 6.96 & 30.70 \\
\hline 10 & 9.00 & 0.266 & 3042 & 11.00 & 2.810 & 1756.0 & 11.23 & 57.70 \\
\hline 10 & 9.00 & 0.266 & 3042 & 12.00 & 3.210 & 2008.0 & 11.63 & 66.00 \\
\hline \multicolumn{9}{|c|}{$\mathrm{MoO}_{4}$} \\
\hline 10 & 9.00 & 0.266 & 3042 & 3.00 & 2.100 & 1314 & 3.12 & 43.20 \\
\hline 10 & 9.00 & 0.266 & 3042 & 4.00 & 1.720 & 1073 & 4.60 & 35.30 \\
\hline 10 & 9.00 & 0.266 & 3042 & 5.00 & 1.490 & 931 & 4.77 & 30.60 \\
\hline 10 & 9.00 & 0.266 & 3042 & 6.00 & 0.307 & 192 & 5.43 & 6.31 \\
\hline 10 & 9.00 & 0.266 & 3042 & 7.00 & 0.327 & 204 & 5.56 & 6.72 \\
\hline 10 & 9.00 & 0.266 & 3042 & 8.00 & 0.303 & 189 & 6.10 & 6.23 \\
\hline 10 & 9.00 & 0.266 & 3042 & 9.00 & 0.458 & 286 & 6.33 & 9.41 \\
\hline 10 & 9.00 & 0.266 & 3042 & 10.00 & 1.320 & 826 & 7.12 & 27.10 \\
\hline 10 & 9.00 & 0.266 & 3042 & 11.00 & 2.180 & 1360 & 10.38 & 44.70 \\
\hline 10 & 9.00 & 0.266 & 3042 & 12.00 & 3.140 & 1960 & 10.57 & 64.40 \\
\hline
\end{tabular}

Arsenate was adsorbed completely at $\mathrm{pH}<9$ in the absence of phosphate. Phosphate (at $\mathrm{pH}$ 5) had the greatest effect on $\mathrm{As}(\mathrm{V})$ desorbed from goethite at $\mathrm{pH} 3(31.6 \%)$, and then its value tended to slightly increase with increasing $\mathrm{pH}$ up to $7(33 \%)$. Above $\mathrm{pH} 7, \mathrm{As}(\mathrm{V})$ greatly increased to $70.6 \%$ at $\mathrm{pH}$ value of 12 . On the other hand, phosphate (at a concentration of 100 times as arsenate and $\mathrm{pH}$ 9) exhibited a more effect on $\mathrm{As}(\mathrm{V})$ desorbed, where its relative increase percentage reached $43.7 \%$ at $\mathrm{pH} \mathrm{3}$, and increased slightly to $46.0 \%$ with increasing $\mathrm{pH}$ up to 7 . Above $\mathrm{pH} 7$, the relative increase percentage of $\mathrm{As}(\mathrm{V})$ exhibited a greatest value of $75.5 \%$ at $\mathrm{pH} 12$. These results indicated that desorption of $\mathrm{As}(\mathrm{V})$ is very sensitive to the changes in $\mathrm{pH}$ values. Similar results obtained by Masscheleyn et al. (1991). The greatest As(V) desorbed as a (76.0 $\%$ ) was achieved by using phosphate at $\mathrm{pH} 5$, yet the desorption of arsenate by phosphate was not complete. Such incomplete desorption of $\mathrm{As}(\mathrm{V})$ may be

Fayoum J. Agric. Res. \& Dev., Vol.23, No.1, January, 2009 
attributed to the formation of bionulear adsorbate complexes of As $(\mathrm{V})$ on goethite surfaces which restrict the rate of desorption process (Sun and Doner, 1996; Fendorf et al., 1997 and Abd El-Haleem et al., 2002).

The sorption of $\mathrm{AsO}_{4}{ }^{3-}$ or $\mathrm{PO}_{4}{ }^{3-}$ on goethite and gibbsite decreased with increasing the initial molar ratio of $\mathrm{PO}_{4}{ }^{3-} / \mathrm{AsO}_{4}{ }^{3-}$ up to 2.0 . However, $\mathrm{PO}_{4}{ }^{3-}$ inhibited $\mathrm{AsO}_{4}{ }^{3-}$ sorption more on gibbsite than on goethite. Whereas, $\mathrm{AsO}_{4}{ }^{3-}$ prevent a more adsorbed of $\mathrm{PO}_{4}{ }^{3-}$ on goethite than gibbsite (Violante and pigna, 2002). Arsenate adsorption on amorphous Fe oxide (Jain and Loeppert, 2000), goethite, gibbsite (Hingston et al., 1971 and Manning and Goldberg, 1996a), kaolinite, montmorillonite, and illite (Manning and Goldberg, 1996b) was significantly reduced by the presence of competing phosphate concentrations.

Desorption of arsenic by sulphate:

Data illustrated in Tables (4 and 5) showed that sulphate (at $\mathrm{pH} 5$ ) had no appreciable effect on $\mathrm{As}(\mathrm{V})$ desorbed at $\mathrm{pH} 3(0.34 \%)$ as well as it was negligible $(0.34 \%)$ with increasing the $\mathrm{pH}$ up to 7 . Above $\mathrm{pH} 7$, As(V) greatly increased to $59.8 \%$ at $\mathrm{pH} 12.0$. While, desorbtion of $\mathrm{As}(\mathrm{V})$ by sulphate (at $\mathrm{pH}$ 9) showed an almost similar results to those at $\mathrm{pH} 3$ and 7 . Similar results were obtained by (Wilkie and Hering, 1996 and Jain and Loeppert, 2000). Arsenate adsorbed on alumina (Xu et $\boldsymbol{a l}$. , 1988) and arsenite adsorption on amorphous $\mathrm{Fe}$ oxide were reduced by competing sulphate concentrations, although to a lesser degree than by competing phosphate concentrations. (Wilkie and Hering, 1996 and Jain and Loeppert, 2000).

Desorption of arsenic by molybdate:

Results of Tables ( 4 and 5 ) indicated that molybdate (at an initial concentration of ratio $100 \mathrm{MoO}_{4}: 1$ As and $\mathrm{pH}$ values of 5 and 9) had a greatest effect on $\mathrm{As}(\mathrm{V})$ desorbed at $\mathrm{pH} 3$, where its relative increase percentages reached 32.0 and $43.2 \%$, respectively. With increasing $\mathrm{pH}$ up to 7 , the relative increase of $\mathrm{As}(\mathrm{V})$ desorbed sharply decreased to $0.10 \%$, and then greatly increased again to $58.9 \%$ at $\mathrm{pH} 12$. Also, molybdate showed a slightly increased $(6.23 \%)$ for $\mathrm{As}(\mathrm{V})$ desorbed with increasing $\mathrm{pH}$ up to 8, and then $\mathrm{As}(\mathrm{V})$ desorbed increased markedly to $64.4 \%$ at $\mathrm{pH} 12$. A similar result obtained by Manning and Goldberg (1996 a \& b) who pointed that there was a competitive effect of molybdate on arsenate adsorption on goethite, gibbsite, kaolinite, montmorillonite and illite.

\section{c. Zerovalent iron:}

\section{Desorption of arsenic by phosphate:}

Arsenate was initially adsorbed at both $\mathrm{pH}$ values of 5 and 9 in the absence of phosphate, Tables (6 and 7), however, the obtained data showed a slightly effect of phosphate on $\mathrm{As}(\mathrm{V})$ desorbed at $\mathrm{pH}$ of 3 and when its value increased up to 7 , where the corresponding relative increase percentages reached 10.10 and $7.08 \%$, respectively. As(V) desorbed increased markedly to $48.1 \%$ at $\mathrm{pH} 12$ in case of phosphate (at $\mathrm{pH} 5$ ). While, phosphate at initial $\mathrm{pH} 9$ had a moderate effect on As (V) desorbed, where the relative increases reached 23.50 and 22.09 at $\mathrm{pH} 3$ and when its value increased up to 7, respectively. Above $\mathrm{pH} 7, \mathrm{As}(\mathrm{V})$ greatly increased to $55.7 \%$ at $\mathrm{pH} 12$ at a concentration ratio of (100:1).

Desorption of arsenic by sulphate:

Arsenate was initially adsorbed at $\mathrm{pH}$ values of 5 and 9 in the absence of sulphate as shown in Tables (6 and 7), and lowest relative increase percentages of 0.28 and $0.08 \%$ of $\mathrm{As}(\mathrm{V})$ desorbed in presence of sulphate were recorded at $\mathrm{pH} 3$ and with increasing its values up to 9 , respectively. Above $\mathrm{pH} 9$ in presence of sulphate and at initial $\mathrm{pH} 5, \mathrm{As}(\mathrm{V})$ desorbed greatly increased to $45.5 \%$ at $\mathrm{pH} 12.0$. On the other hand, in presence of sulphate and at initial $\mathrm{pH} 9$, $\mathrm{As}(\mathrm{V})$ desorbed showed also lowest relative increases of 0.93 and $1.79 \%$ at $\mathrm{pH}$ 3 and with increasing its values up to $\mathrm{pH} 8$, respectively. Above $\mathrm{pH} 8, \mathrm{As}(\mathrm{V})$ increased markedly to $65.8 \%$ at $\mathrm{pH} 12$ and at a concentration ratio of 100 sulphate : 1 arsenate.

Fayoum J. Agric. Res. \& Dev., Vol.23, No.1, January, 2009 
DESORPTION OF ARSENIC FROM SOIL, GOETHITE AND...........

Table (6): Arsenate desorption from zerovalent, at the initial pH 5, by $\mathrm{PO}_{4}, \mathrm{SO}_{4}$ and $\mathrm{MoO}_{4}$ under a wide range of $\mathrm{pH}$, concentration of $10 \mu \mathrm{g} \mathrm{As} \mathrm{mL}$ and $0.1 \mathrm{M} \mathrm{NaCl}$ as ionic strength.

\begin{tabular}{|c|c|c|c|c|c|c|c|c|}
\hline \multirow{2}{*}{$\begin{array}{c}\text { Initial } \\
\text { concentration of } \\
\text { As }\left(\mu \mathrm{g} \mathrm{mL}^{-1}\right)\end{array}$} & \multicolumn{3}{|c|}{ Adsorbed As } & \multicolumn{3}{|c|}{ Desorbed As } & \multirow{2}{*}{$\begin{array}{c}\text { Final } \\
\mathrm{pH}\end{array}$} & \multirow{2}{*}{$\begin{array}{c}\text { Desorbed } \\
\text { As }\end{array}$} \\
\hline & \begin{tabular}{|c|} 
Initial \\
$\mathrm{pH}$
\end{tabular} & $\begin{array}{l}\text { Concentration } \\
\left(\mu \mathrm{gL} \mathrm{m}^{-1}\right)\end{array}$ & \begin{tabular}{|l|} 
Quantity \\
$\left(\mu \mathrm{g} \mathrm{g}^{-1}\right)$
\end{tabular} & \begin{tabular}{|c|} 
Initial \\
$\mathrm{pH}$
\end{tabular} & $\begin{array}{c}\text { Concentration } \\
\left(\mu \mathrm{g} \mathrm{mL}^{-1}\right)\end{array}$ & \begin{tabular}{|c|} 
Quantity \\
$\left(\mu \mathrm{g} \mathrm{g}^{-1}\right)$
\end{tabular} & & \\
\hline \multicolumn{9}{|c|}{$\mathrm{PO}_{4}$} \\
\hline 10 & 5.00 & 0.000 & 25000 & 3.00 & 0.504 & 2520 & 3.50 & 10.10 \\
\hline 10 & 5.00 & 0.000 & 25000 & 4.00 & 0.366 & 1830 & 3.50 & 7.32 \\
\hline 10 & 5.00 & 0.000 & 25000 & 5.00 & 0.356 & 1780 & 3.80 & 7.12 \\
\hline 10 & 5.00 & 0.000 & 25000 & 6.00 & 0.359 & 1795 & 4.45 & 7.18 \\
\hline 10 & 5.00 & 0.000 & 25000 & 7.00 & 0.354 & 1770 & 6.48 & 7.08 \\
\hline 10 & 5.00 & 0.000 & 25000 & 8.00 & 0.382 & 1910 & 7.42 & 7.64 \\
\hline 10 & 5.00 & 0.000 & 25000 & 9.00 & 0.421 & 2105 & 8.00 & 8.42 \\
\hline 10 & 5.00 & 0.000 & 25000 & 10.00 & 1.890 & 9450 & 8.00 & 37.80 \\
\hline 10 & 5.00 & 0.000 & 25000 & 11.00 & 2.270 & 11325 & 8.00 & 45.30 \\
\hline 10 & 5.00 & 0.000 & 25000 & 12.00 & 2.410 & 12025 & 10.00 & 48.10 \\
\hline \multicolumn{9}{|c|}{$\mathrm{SO}_{4}$} \\
\hline 10 & 5.00 & 0.000 & 25000 & 3.00 & 0.014 & 70 & 2.55 & 0.28 \\
\hline 10 & 5.00 & 0.000 & 25000 & 4.00 & 0.024 & 120 & 3.55 & 0.48 \\
\hline 10 & 5.00 & 0.000 & 25000 & 5.00 & 0.011 & 55 & 3.60 & 0.22 \\
\hline 10 & 5.00 & 0.000 & 25000 & 6.00 & 0.016 & 80 & 4.50 & 0.32 \\
\hline 10 & 5.00 & 0.000 & 25000 & 7.00 & 0.004 & 20 & 4.50 & 0.08 \\
\hline 10 & 5.00 & 0.000 & 25000 & 8.00 & 0.000 & 0.00 & 5.00 & 0.00 \\
\hline 10 & 5.00 & 0.000 & 25000 & 9.00 & 0.000 & 0.00 & 6.00 & 0.00 \\
\hline 10 & 5.00 & 0.000 & 25000 & 10.00 & 0.322 & 1610 & 8.00 & 6.44 \\
\hline 10 & 5.00 & 0.000 & 25000 & 11.00 & 1.940 & 9715 & 11.00 & 38.90 \\
\hline 10 & 5.00 & 0.000 & 25000 & 12.00 & 2.280 & 11375 & 12.00 & 45.50 \\
\hline \multicolumn{9}{|c|}{$\mathrm{MoO}_{4}$} \\
\hline 10 & 5.00 & 0.000 & 25000 & 3.00 & 1.660 & 8310 & 3.00 & 33.20 \\
\hline 10 & 5.00 & 0.000 & 25000 & 4.00 & 0.060 & 300 & 4.80 & 1.20 \\
\hline 10 & 5.00 & 0.000 & 25000 & 5.00 & 0.000 & 0.00 & 4.80 & 0.00 \\
\hline 10 & 5.00 & 0.000 & 25000 & 6.00 & 0.000 & 0.00 & 5.11 & 0.00 \\
\hline 10 & 5.00 & 0.000 & 25000 & 7.00 & 0.000 & 0.00 & 5.20 & 0.00 \\
\hline 10 & 5.00 & 0.000 & 25000 & 8.00 & 0.015 & 75 & 6.00 & 0.30 \\
\hline 10 & 5.00 & 0.000 & 25000 & 9.00 & 0.035 & 175 & 6.00 & 0.70 \\
\hline 10 & 5.00 & 0.000 & 25000 & 10.00 & 1.230 & 6125 & 7.00 & 24.50 \\
\hline 10 & 5.00 & 0.000 & 25000 & 11.00 & 1.710 & 8570 & 8.00 & 34.30 \\
\hline 10 & 5.00 & 0.000 & 25000 & 12.00 & 1.990 & 9965 & 9.00 & 39.90 \\
\hline
\end{tabular}

Desorption of arsenic by molybdate:

Arsenate was desorbed or extracted by molybdate at initial $\mathrm{pH} 5$, and the obtained data in Tables (6 and 7) declared a greatest value of $\mathrm{As}(\mathrm{V})$ desorbed $(33.2 \%)$ at $\mathrm{pH} 3$, and it tended to decreased sharply (0.00) with increasing $\mathrm{pH}$ up to 7 , while it greatly increased again to $39.9 \%$ at $\mathrm{pH} 12$. Also, As(V) was initially desorbed at $\mathrm{pH} 9$ by molybdate, where a greatest value of $\mathrm{As}(\mathrm{V})$ desorbed $(51.93 \%)$ was achieved at $\mathrm{pH} 3$, then it tended to a sharply decrease $(1.30 \%)$ with increasing $\mathrm{pH}$ up to 7 . Above $\mathrm{pH} 7, \mathrm{As}(\mathrm{V})$ greatly increased again to $55.8 \%$ at $\mathrm{pH} 12$ at a concentration ratio of $100 \mathrm{MoO}_{4}: 1$ As. Desorption of As(V) from goethite by phosphate, sulphate and molybdate was highly dependent on $\mathrm{pH}$ values, the greatest $\mathrm{As}(\mathrm{V})$ desorbed values were recorded at the relatively low and high $\mathrm{pH}$ values, which in no case achieved greater than (70$75 \%)$, (59.9-66\%) and (59-64\%) in cases of using phosphate, sulphate and molybdate on goethite at $\mathrm{pH}(5-9)$, respectively.

Fayoum J. Agric. Res. \& Dev., Vol.23, No.1, January, 2009 
Table (7): Arsenate desorption from zerovalent, at the initial pH 9, by $\mathrm{PO}_{4}, \mathrm{SO}_{4}$ and $\mathrm{MoO}_{4}$ under a wide range of $\mathrm{pH}$, concentration of $10 \mu \mathrm{g} \mathrm{As} \mathrm{mL}^{-1}$ and $0.1 \mathrm{M} \mathrm{NaCl}$ as ionic strength.

\begin{tabular}{|c|c|c|c|c|c|c|c|c|}
\hline \multirow{2}{*}{$\begin{array}{c}\text { Initial } \\
\text { concentration of } \\
\text { As }\left(\mu \mathrm{g} \mathrm{mL}^{-1}\right)\end{array}$} & \multicolumn{3}{|c|}{ Adsorbed As } & \multicolumn{3}{|c|}{ Desorbed As } & \multirow{2}{*}{$\begin{array}{c}\text { Final } \\
\mathrm{pH}\end{array}$} & \multirow{2}{*}{$\begin{array}{c}\text { Desorbed } \\
\text { As }\end{array}$} \\
\hline & $\begin{array}{c}\text { Initial } \\
\mathrm{pH}\end{array}$ & $\begin{array}{c}\text { Concentration } \\
\left(\mu \mathrm{g} \mathrm{mL}^{-1}\right)\end{array}$ & $\begin{array}{l}\text { Quantity } \\
\left(\mu g^{-1}\right)\end{array}$ & $\begin{array}{c}\text { Initial } \\
\mathrm{pH}\end{array}$ & $\begin{array}{c}\text { Concentration } \\
\left(\mu \mathrm{g} \mathrm{mL}^{-1}\right)\end{array}$ & $\begin{array}{l}\text { Quantity } \\
\left(\mu g^{-1}\right)\end{array}$ & & \\
\hline \multicolumn{9}{|c|}{$\mathrm{PO}_{4}$} \\
\hline 10 & 9.00 & 0.303 & 24243 & 3.00 & 1.14 & 5700 & 2.70 & 23.50 \\
\hline 10 & 9.00 & 0.303 & 24243 & 4.00 & 1.04 & 5175 & 4.00 & 21.40 \\
\hline 10 & 9.00 & 0.303 & 24243 & 5.00 & 1.07 & 5370 & 4.11 & 22.20 \\
\hline 10 & 9.00 & 0.303 & 24243 & 6.00 & 1.10 & 5505 & 5.29 & 22.70 \\
\hline 10 & 9.00 & 0.303 & 24243 & 7.00 & 1.07 & 5355 & 7.00 & 22.10 \\
\hline 10 & 9.00 & 0.303 & 24243 & 8.00 & 1.16 & 5820 & 7.30 & 24.00 \\
\hline 10 & 9.00 & 0.303 & 24243 & 9.00 & 1.33 & 6630 & 7.46 & 27.40 \\
\hline 10 & 9.00 & 0.303 & 24243 & 10.00 & 1.67 & 8365 & 7.63 & 34.50 \\
\hline 10 & 9.00 & 0.303 & 24243 & 11.00 & 2.41 & 12050 & 11.00 & 49.70 \\
\hline 10 & 9.00 & 0.303 & 24243 & 12.00 & 2.70 & 13520 & 11.50 & 55.80 \\
\hline \multicolumn{9}{|c|}{$\mathrm{SO}_{4}$} \\
\hline 10 & 9.00 & 0.303 & 24243 & 3.00 & 0.045 & 225 & 3.00 & 0.93 \\
\hline 10 & 9.00 & 0.303 & 24243 & 4.00 & 0.061 & 305 & 3.36 & 1.26 \\
\hline 10 & 9.00 & 0.303 & 24243 & 5.00 & 0.201 & 1005 & 4.50 & 4.15 \\
\hline 10 & 9.00 & 0.303 & 24243 & 6.00 & 0.000 & 0.00 & 5.00 & 0.000 \\
\hline 10 & 9.00 & 0.303 & 24243 & 7.00 & 0.105 & 525 & 6.00 & 2.17 \\
\hline 10 & 9.00 & 0.303 & 24243 & 8.00 & 0.087 & 435 & 6.00 & 1.79 \\
\hline 10 & 9.00 & 0.303 & 24243 & 9.00 & 0.283 & 1415 & 6.40 & 5.84 \\
\hline 10 & 9.00 & 0.303 & 24243 & 10.00 & 0.628 & 3140 & 6.50 & 13.00 \\
\hline 10 & 9.00 & 0.303 & 24243 & 11.00 & 2.09 & 10440 & 8.00 & 43.10 \\
\hline 10 & 9.00 & 0.303 & 24243 & 12.00 & 3.19 & 15950 & 12.00 & 65.80 \\
\hline \multicolumn{9}{|c|}{$\mathrm{MoO}_{4}$} \\
\hline 10 & 9.00 & 0.303 & 24243 & 3.00 & 2.52 & 12590 & 2.00 & 51.90 \\
\hline 10 & 9.00 & 0.303 & 24243 & 4.00 & 1.32 & 6605 & 4.75 & 27.30 \\
\hline 10 & 9.00 & 0.303 & 24243 & 5.00 & 0.115 & 575 & 4.75 & 2.37 \\
\hline 10 & 9.00 & 0.303 & 24243 & 6.00 & 0.102 & 510 & 5.00 & 2.10 \\
\hline 10 & 9.00 & 0.303 & 24243 & 7.00 & 0.063 & 315 & 5.20 & 1.30 \\
\hline 10 & 9.00 & 0.303 & 24243 & 8.00 & 0.187 & 935 & 6.00 & 3.86 \\
\hline 10 & 9.00 & 0.303 & 24243 & 9.00 & 0.191 & 955 & 6.00 & 3.94 \\
\hline 10 & 9.00 & 0.303 & 24243 & 10.00 & 0.862 & 4310 & 7.00 & 17.80 \\
\hline 10 & 9.00 & 0.303 & 24243 & 11.00 & 1.48 & 7400 & 7.30 & 30.50 \\
\hline 10 & 9.00 & 0.303 & 24243 & 12.00 & 2.70 & 13520 & 12.00 & 55.80 \\
\hline
\end{tabular}

Also, The greatest As desorbed from ferrihydrite was at low and high $\mathrm{pH}$ values, but in no case achieved greater than (73-68.8\%), (70-64\%) and (69.9$53.9 \%$ ) in case of using phosphate, sulphate and molybdate at $\mathrm{pH}$ (5-9), respectively (Jain and Loeppert, 2000). The corresponding values for zerovalent iron were (48.1-55.7\%), (45.4-65.8\%) and (39.9-55.8\%) in cases of presence phosphate, sulphate and molybdate at $\mathrm{pH}$ (5-9), respectively. These results are in agreement with those reported by Hiemstra and Riemsdijk (1999) who showed that application of phosphate fertilizer has been affected the mobility of arsenic in soils. Also, excess of phosphate has been used to displacement As(V) from sediments, fly ash, and soils, but the displacement is slow and often incomplete (Peryea, 1991).

It could be concluded that $\mathrm{SO}_{4}{ }^{=}$ions, under the initial $\mathrm{pH}$ values of 5 and 9 , failed to extract or replace arsenate adsorbed on goethite and zerovalent iron at $\mathrm{pH}$ range of 3 to 8 . At $\mathrm{pH}<6$ and $>9$, both of phosphate and molybedate were

Fayoum J. Agric. Res. \& Dev., Vol.23, No.1, January, 2009 
able to extract appreciable quantities of $\mathrm{As}(\mathrm{V})$ initially adsorbed on goethite and zerovalent iron at $\mathrm{pH}$ values of 5 and 9 . Also, phosphate and molybedate can be extracted As (V) adsorbed, except in the case of As(V) adsorbed on zerovalent iron at $\mathrm{pH} 5$ where phosphate did not succeed to extract appreciable quantities of the adsorbed $\mathrm{As}(\mathrm{V})$ at $\mathrm{pH}$ ranged from 3 to 9.

\section{REFERECES:}

Abd El-Haleem, A.A.; R.H. Loepert and L.R. Hossner 2002. Kinetics of arsenite and arsenate desorption from goethite. J. Agric. Sci. Mansoura Univ., 27: 7149-7161.

Arai, Y. and D.L.Sparks 2002. Residence time effects on arsenate surface speciation at the aluminum oxide-water interface. Soil Sci., 167: 303-314.

Black, C.A. (Ed.). 1965. Methods of Soil Analysis Parts 1 and 2, Am. Society of Agronomy, Inc. Pub., Madison, Wisconsin, USA.

Brown, G. 1961. The X-ray identification and crystal structures of clay minerals. Mineralogical Society, 41Queen's Gate, London, S.W.7.

Chen-Wuing, L.;W. Sheng-Wei; J. Cheng-Shin and L. Kao-Hong 2006. Occurrence of arsenic in ground water in the choushui river alluvial fan, Taiwan. J. Environ. Qual., 35: 68-75.

Fendorf, S.; M.J. Eick; P. Grossl and D.L. Sparks 1997. Arsenate and chromate retention mechanisms on goethite. I: Surface structure. Environ. Sci. Technol., 31: $315-320$.

Hiemstra, T. and W.H. Van Riemsdijk 1999. Surface structural ion adsorption modeling of competitive binding of oxyanions by metal (hydr) oxides. J. Colloid and lnterface Sci., 210: 182 - 193.

Hingston, F.J.; A.M. Posner and J.P. Quirk 1971. Competitive adsorption of negatively charged ligands on oxide surface. Discuss. Faradgy Soc., 52: 334-342.

Jain, A.; and R.H. Loeppert 2000. Effect of competing anions on the adsorption of arsenate and arsenite by ferrihydrite. J. Environ Qual., 29: 1422-1430.

Manning, B.A. and S. Goldberg 1996a. Modeling competitive adsorption of arsenate with phosphate and molybdate on oxide minerals. Soil Sci. Soc. Am. J., 60: 121-131.

Manning, B.A, and S. Goldberg 1996b. Modeling arsenate competitive adsorption on kaolinite, montmorillonite and illite clays. Clay Miner., 44: 609-623.

Masscheleyn, P.H.; D. Delaune and W.H. Patrick 1991. Effect of redox potential and $\mathrm{pH}$ on arsenic speciation and solubility in a contaminated soil. Environ. Sci. Technol., 25: 1414-1419.

Page, A.I.; R.H. Miller and D.R. Keeney (Eds.). 1982. Methods of Soil Analysis. Part 2: Chemical and Microbiological Properties. $2^{\text {nd }}$ Edition, Amer. Soc. of Agron., Madison, Wisconsin, U.S.A.

Peryea, F.J. 1991. Phosphate induced release of arsenic from soils contaminated with lead arsenate. Soil Sci. Soc. Am. J., 55: 1301-1306.

Raven, K.; A. Jain, and R.H. Loeppert 1998. Arsenite and arsenate adsorption on ferrihydrite, kinetics, equilibrium, and adsorption envelopes. Environ. Sci. Technol., 32: 344-349.

Quaghebeur, M.; A. Rate; Z. Rengel and C. Hinz 2005. Desorption kinetics of arsenate from kaolinite as influenced by pH. J. Environ. Qual., 34: 479-486.

Quaghebeur, M. and Z.Rengel 2004. Phosphate and arsenate interaction in the rhizosphere of canola (Brassica napus). Funct. Plant Biol., 31: 1085-1094.

Schwertmann, U. and R.M. Cormell 1991. Iron Oxides in the Laboratory. Wiley$\mathrm{VCH}$, Weinheim.

Sun, X. and H.E. Doner 1996. An investigation of arsenate and arsenite bonding structures on goethite by FTIR. Soil Sci., 161: 865-872.

Venkatarathnam, K. and W.B.F. Ryan 1971. Dipersal patterns of clay minerals in the sediments of Eastern Mediterranean Sea. Marine Geol., 11: 261-282.

Violante, A, and M. Pigna 2002. Competitive sorption of arsenate and phosphate on different clay minerals and soils. Soil Sci. Soc. Am. J., 66: 1788-1796.

Fayoum J. Agric. Res. \& Dev., Vol.23, No.1, January, 2009 
Wenzel, W.W.; N. Kirchboumer; T. Prohaska; G. Stingeder; E. Lombi and D.C. Adriano 2001. Arsenic fractionation in soil using an improved sequential extraction procedure. Anal. Chim. Acta, 436: 309-323.

Wilkie, J.A. and J.G. Hering 1996. Desorption of arsenic onto hydrous ferric oxide: Effects of adsorbate/adsorbent ratios Co- occurring solutes. Coll. Suurf., 107: 97110.

Xu, H.; B. Allard and A. Grimvall 1988. Influence of $\mathrm{pH}$ substance on the adsorption of A (V) on geological materials. Water Air Soil Pollut., 40: 293-305.

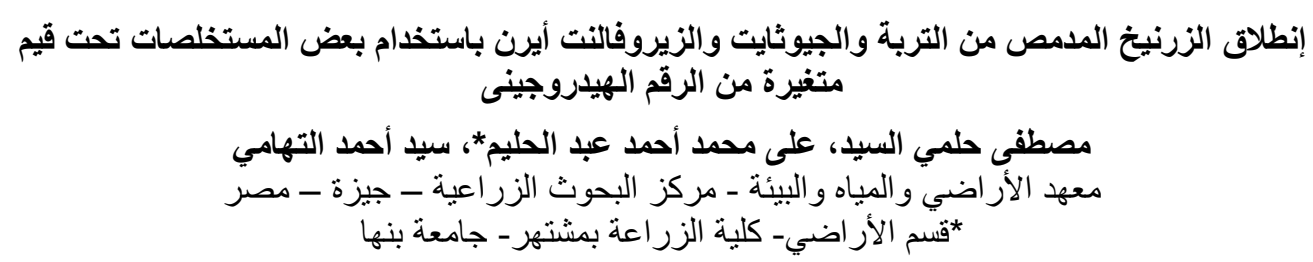

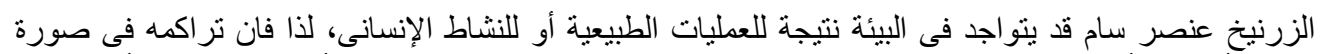

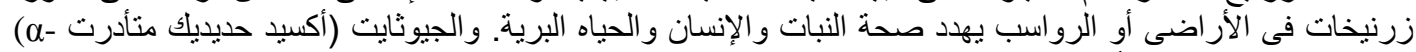
FeOOH

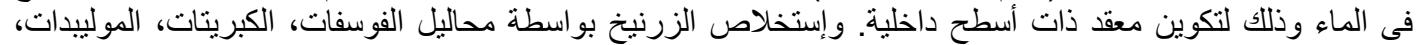

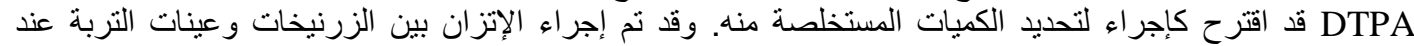

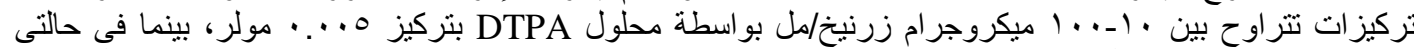

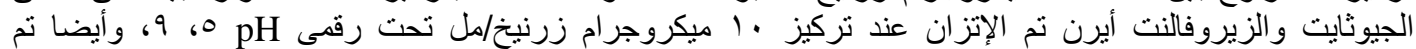

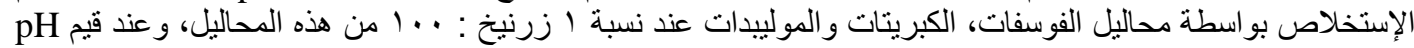

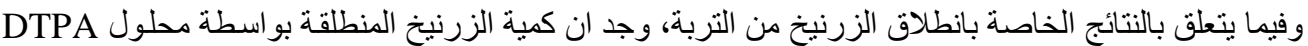

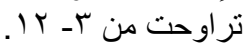

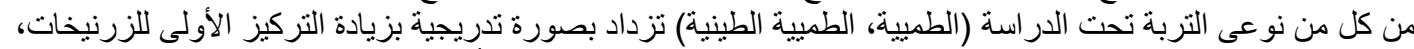

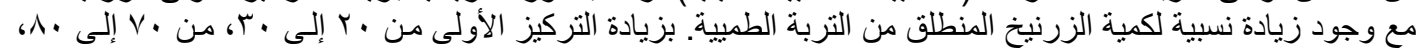

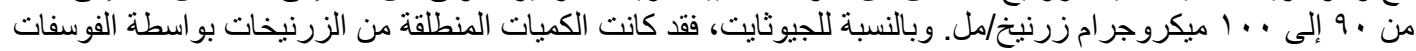

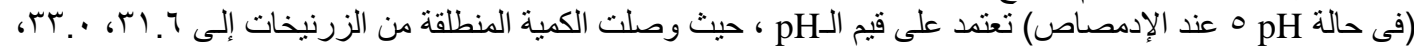

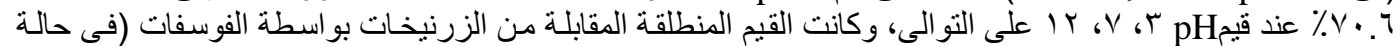

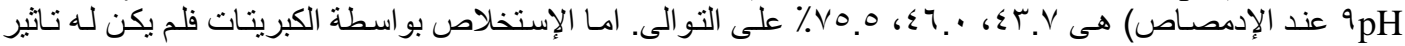

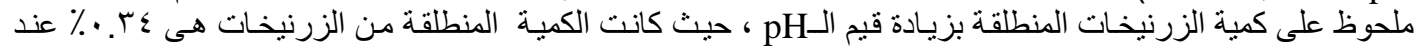

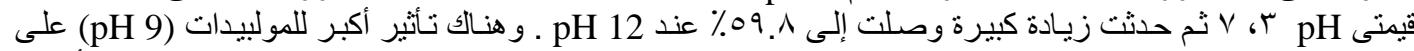

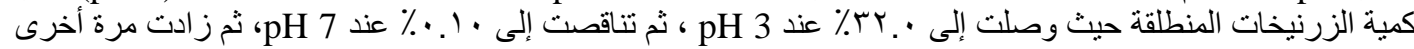

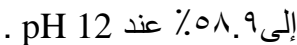

وفيما يختص بالزيروف الالنت أيرن، فان النتائج تثبير إلى أن الكميات المنطلقة من الزرنيخات بو اسطة الفوسفات (فى

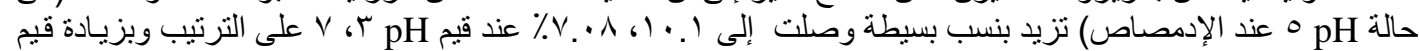

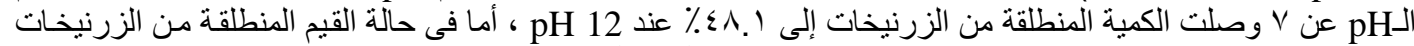

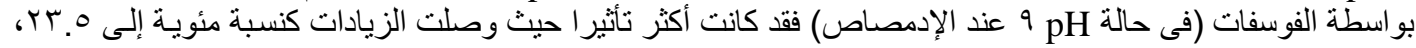

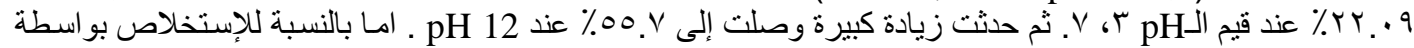

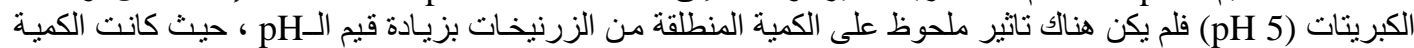

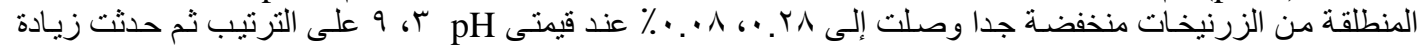

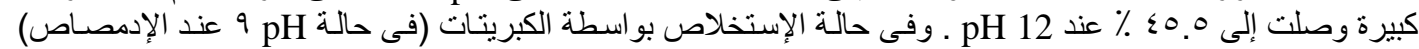

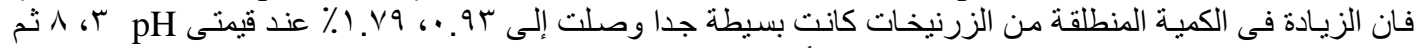

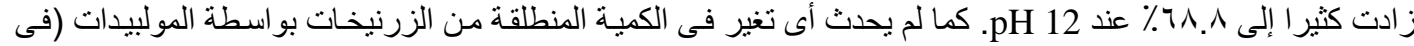

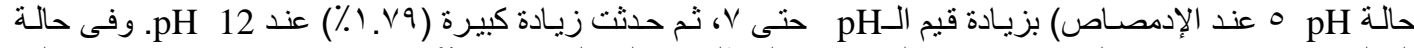

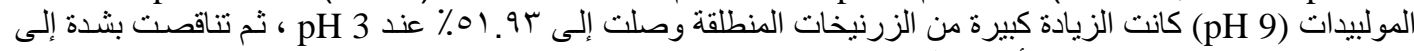

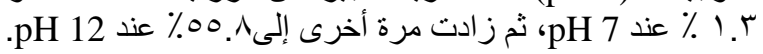

Fayoum J. Agric. Res. \& Dev., Vol.23, No.1, January, 2009 